\title{
Strategies for Human Adipose Tissue Repair and Regeneration
}

\author{
Asun Monfort ${ }^{1}$, Ander Izeta ${ }^{2 *}$ \\ ${ }^{1}$ Wellcome Trust-Medical Research Council Stem Cell Institute, University of Cambridge, Cambridge, UK; ${ }^{2}$ Instituto Biodonostia, \\ Hospital Universitario Donostia, San Sebastián, Spain. \\ Email: *ander.izeta@biodonostia.org
}

Received May $11^{\text {th }}, 2012$; revised June $12^{\text {th }}, 2012$; accepted July $15^{\text {th }}, 2012$

\begin{abstract}
In plastic and reconstructive surgery there is an increasing demand for malleable implants to repair soft tissue congenital defects, or those resulting from aging, traumatic injury and tumour resection. However, currently available methods present a number of limitations such as volume loss over time and eventual resorption of the graft. Tissue engineering techniques provide promising therapeutic solutions to these inconveniences through development of engineered equivalents that best imitate adipose tissue, both structurally and functionally. Here we review the latest achievements in the human adipose tissue engineering field, with a focus on its regenerative potential for a number of clinical applications.
\end{abstract}

Keywords: Adipose Tissue Engineering; Soft Tissue Regeneration; Stem Cells

\section{Introduction}

Adipose tissue is a highly vascularized connective tissue, ubiquitous throughout the human body. It is responsible for energy storage and release of a number of adipokines that may act in an endocrine or paracrine fashion [1]. It is also a highly plastic tissue than can increase energy depots by hypertrophic growth and hyperplasic expansion of adipose stromal cells (ASCs) [2]. It contains many cell types including adipocytes, ASCs (a term that refers to the tissue-resident mesenchymal stromal cells (MSCs) and adipose progenitor cell populations), endothelial cells (ECs), fibroblasts, macrophages and leukocytes.

The human adipose tissue can be found either in the white adipose tissue (WAT) or the brown adipose tissue (BAT) form. WAT is the most abundant form in humans and it accumulates energy in the form of triacylglycerols. WAT is composed of large spherical or ovoid cells 60 $80 \mu \mathrm{m}$ in diameter, characterized by a single lipid droplet that accounts for about $90 \%$ of the cell volume. The lipid droplet provokes peripheral displacement of the nucleus and appearance of a variable number of round or elongated mitochondria with short and randomly oriented cristae [3-5]. Unlike WAT, BAT is characterized by polygonal shaped cells, $30-50 \mu \mathrm{m}$ in size, with complex internal structure of mitochondria which confers to these cells their characteristic brown coloration, granular appearance of the cytoplasm and the near absence of cytoplasmic

${ }^{*}$ Corresponding author. membranes [5]. Brown fat cells present the ability to dissipate energy by producing heat to ensure body temperature regulation, rather than storing it as triglycerides [3]. Whether such thermogenic properties also play a role in body weight regulation and metabolic disorders is still being debated [6-10].

Tissue engineering is the interdisciplinary field where materials, cells, growth factors and other bioactive molecules are combined together to make transplantable constructs, the final goal being to promote repair and regeneration of damaged tissue [11]. Loss or damage of adipose tissue needs repair and regenerative approaches not only for the cosmetical impact of absent tissue but also for the emotional well being of the patients. In some cases damaged adipose tissue may even impair functionality of the affected organ. The first reported fat tissue repair was performed in 1893 by Neuber, who transplanted a fat graft to fill soft tissue depressions on the face [12]. In the following years several authors tried to refine the technique with variable results $[13,14]$. In 1956, Peer et al. transplanted autologous subcutaneous adipose tissue from the abdomen into the face and breast of a patient and stated that large grafts eventually lead to adiponecrotic cyst formation and resorption [15]. In 1999, Patrick et al. reported the generation of the first in vitro fat construct using poly(lactic-co-glycolic) (PLGA) scaffolds and rat preadipocytes [16], but its long-term maintenance remained elusive at 12 month follow-up [17]. Since then, several attempts have been made for soft-tissue repair 
and regeneration with different strategies but the medical need is still considered as "unmet" in terms of safety and efficacy [18], long-term sustainability, and optimal aesthetical results of the grafted tissue [19].

Tissue engineering strategies thus hold great promise to hopefully offer a permanent solution for adipose tissue repair and regeneration in the near future. All the strategies discussed in this review present different advantages and disadvantages and the choice of one or the other must be carefully studied in a case by case basis (Table 1).

\section{Autologous Fat Transfer}

Autologous fat transfer is the technique most used clinically for fat tissue repair. It consists of the removal of the fat from one area of the body to be reinserted into a separate location, where it will fill subcutaneous tissue loss. It is a minimally invasive and safe procedure that allows patients to benefit from autologous tissue transplantation with minimal risk of immune rejection or transmission of viral pathogens.

Its applications range from severe conditions such as facial lipoatrophy [20-23], Parry-Romberg syndrome [24] and schleroderma $[25,26]$, cranio maxillo-facial deformities [27], mastectomy or breast volume augmentation [28-30] or chronic ulceration [31]; to cosmetic applications such as rejuvenation [32-34], gluteal [35] and labia majora augmentation [36] or phalloplasty [37] (Table 2).

However, autologous fat transfer rarely achieves longterm volume augmentation due to the limited survival of mature adipocytes after the liposuction trauma and the poor revascularization that leads to cyst formation and an eventual resorption of the graft [38-40]. Even if some authors have observed up to 8 years permanence of the graft in some conditions [18], most of the studies evidence varying degrees of resorption over time with only a small percentage (30\%) of the graft presenting long-term survival beyond the first year; success being attributed at least partly to the presence of ASCs within the graft $[41,42]$. As a result, complications such as contour irregularity; lumpiness and unpredictability of the graft take and final shape make the grafting technique inefficient and unsuccessful.

In an attempt to overcome low revascularization, vascularized flaps have been used. They consist of skin and

Table 1. Strategies for soft tissue repair and regeneration.

\begin{tabular}{|c|c|c|}
\hline Strategy & Advantages & Disadvantages \\
\hline Non vascularized autologous fat transfer & $\begin{array}{l}\text { - Non immunogenic } \\
\text { - Minimally invasive } \\
\text { - Safe }\end{array}$ & Unpredictable results \\
\hline Vascularized autologous fat transfer & $\begin{array}{l}\text { - Non immunogenic } \\
\text { - Long term survival }\end{array}$ & $\begin{array}{l}\text { - Invasive } \\
\text { - Donor-site morbidity } \\
\text { - Scarring }\end{array}$ \\
\hline $3 \mathrm{D}$ adipose tissue engineering in vitro & $\begin{array}{l}\text { - Treatment of large soft tissue defects } \\
\text { - Control of size and shape }\end{array}$ & $\begin{array}{l}\text { - Prevascularization needed } \\
\text { - Invasive } \\
\text { - Scarring }\end{array}$ \\
\hline Adipose tissue engineering in vivo & $\begin{array}{l}\text { - Minimally invasive } \\
\text { - No prevascularization needed } \\
\text { - Long-term persistance } \\
\text { - Treatment of irregular defect sites } \\
\text { - Non scarring }\end{array}$ & $\begin{array}{l}\text { - Valid only for small volume loss } \\
\text { - Unpredictable shape }\end{array}$ \\
\hline
\end{tabular}

Table 2. Strategies for fat tissue repair and regeneration currently available in the clinic.

\begin{tabular}{|c|c|c|c|}
\hline Strategy & Clinical indication & Outcome & References \\
\hline \multirow{10}{*}{ Autologous fat transfer } & - Lipoatrophy & & $20-23$ \\
\hline & - Parry-Romberg syndrome & & 24,25 \\
\hline & - Schleroderma & & 26 \\
\hline & - Cranio maxillo-facial deformities & & 27 \\
\hline & - Breast reconstruction & Generally, good results in the short term & $28-30$ \\
\hline & - Chronic ulceration & but unpredictable in the long term & 31 \\
\hline & - Face Rejuvenation & & $32-34$ \\
\hline & - Gluteal augmentation & & 35 \\
\hline & - Labia majora augmentation & & 36 \\
\hline & - Phalloplasty & & 37 \\
\hline \multirow{3}{*}{$\begin{array}{c}\text { Injection of in vitro differentiated } \\
\text { adipocytes }\end{array}$} & - Eyelid wrinkles & & 45 \\
\hline & $\begin{array}{l}\text { - Deep nasolabial folds } \\
\text { - Less projected forehead }\end{array}$ & Good sustained correction & \\
\hline & - Depressed scars & & 46 \\
\hline
\end{tabular}


fat removed together with blood vessels and transferred to the desired area. However the use of flaps is also limited by donor site defect, infection, unstability and wound healing disorders [43]. The latest surgical approach for autologous fat transfer is the lipofilling technique, which consists of the injection of microportions of autologous fat obtained from non-traumatic vacuum aspiration. In combination with cells isolated from the adipose stromal vascular fraction, this technique has proved to be effective, safe and superior to conventional lipoinjection $[42,44]$. Some authors report that even the sole injection of in vitro differentiated autologous adipocytes is an effective strategy to achieve soft tissue augmentation $[45,46]$.

Despite the comprehensive efforts of a number of fully dedicated clinicians, a standard procedure for harvesting and processing of cells, injection and reinjection site has not been developed as of yet. All of the above are key elements to be considered for a successful autologous fat transfer, although many other factors might also affect the final outcome $[18,47,48]$.

\section{Adipose Tissue Engineering}

Adipose tissue engineering is recently gaining significant importance due to the increasing need for clinical soft tissue filler procedures and the known impact of ASCs and their secretions in wound healing $[49,50]$. Currently, most adipose tissue engineering approaches include two different strategies: in situ adipogenesis for small volume loss, and 3D in vitro tissue engineering for large adipose tissue defects. Both strategies usually imply the use of living cells and/or biomolecules and/or biocompatible scaffolds.

\subsection{Cells}

\subsubsection{MSCs and Adipocytes}

The ideal cell population for any tissue engineering strategy should present the following characteristics: 1) Autologous or at least non-immunogenic; 2) Available in sufficient quantities or easy to propagate in vitro with no loss of differentiation potential; and 3) Easy to harvest with minimally invasive procedures [51].

One of the barriers that hampered the in vitro fat tissue development was the impossibility to maintain the longterm culture of mature adipocytes ex vivo [52-55]. Mature adipocytes are prone to mechanical damage during fat tissue manipulation and also highly susceptible to ischemic death. Moreover, they are terminally differentiated and thus unable to proliferate. These characteristics make them unsuitable for regenerative purposes [56]. Recently we developed a new culture method for adipocytes using a plasma hydrogel scaffold. We were able to maintain an in vitro adipocyte culture with minimal medium change for 2 years, a considerable improvement over previous reports [57].

The use of ASC and bone marrow MSCs (BM-MSC) has been reported in several studies and patents for adipose tissue engineering $[58,59]$. The Mesenchymal and Tissue Stem Cell Committee of the International Society for Cellular Therapy (ISCT) proposed minimal criteria for defining MSCs. They must be plastic-adherent, demonstrate the expression of the surface markers CD105, CD73, and CD90 and show minimal or null expression of CD45, CD34, CD14 or CD11b, CD79a or CD19 and HLA Class II proteins. Finally, MSCs must demonstrate the ability to differentiate to osteogenic, adipogenic and chondrogenic lineages. Mesenchymal stromal cells are preferred over mature adipocytes due to their capacity to proliferate in vitro while maintaining their multilineage differentiation potential [60] to bone [61], cartilage, fat [62] and vessels [63]. Besides, they possess angiogenic and anti-inflammatory properties [64] and an interesting secretome with highly variable quantities of proteins that may play important roles in regenerative environment, such as hepatocyte growth factor (HGF) and vascular endothelial growth factor (VEGF) $[65,66]$.

A number of studies reported different strategies to develop 3D adipose tissue constructs using ASC or BMMSC as the cellular starting material: Vermette et al. and Vallée et al. used the so called "self-assembly strategy" [67] to recreate three-dimensional adipose substitutes in vitro devoid of exogenous biomaterials [68,69]. After 21 - 28 days' culture, stimulation of extracellular matrix (ECM) secretion by ascorbic acid and induction of adipogenesis, cells show a robust differentiation potential. Monfort et al. embedded ASC and BM-MSC within fibrin scaffolds and proved similar usefulness for adipocytic differentiation of this material, leading to formation of an adipose construct after 21 days' culture [57]. Other authors have used diverse scaffolds such as collagen, gelatin or silk-fibroin [70-72].

\subsubsection{Endothelial Cells (EC)}

A second main obstacle for in vitro fat tissue development, as yet unresolved, is the low in vivo revascularization of large volume adipose tissue grafts. Lack of vascularization leads to grafted tissue shrinkage, fibrosis and oil cyst formation. Implanted tissues need days or weeks to develop new blood vessels and during this process an insufficient supply of nutrients and oxygen may compromise the viability of the graft $[73,74]$. To create functional vascularization, an intact endothelial layer covering the inner side of branched vessel structures with a maximum distance between capillaries of approximately $200 \mu \mathrm{m}$ is needed [75]. In order to achieve this goal, different approaches have been proposed: 1) Endothelial cell-based strategies to form new vessels; 2) Scaffoldbased strategies focused on the generation of biologically 
or synthetically-derived vessel systems $[75,76]$; 3) In vivo integration of vascular pedicles [77]. The latter needs several surgical interventions and morbidity and invasiveness of the procedure are major concerns to be considered for risk/benefit analyses.

In vitro prevascularization consists of seeding the scaffolds with EC alone or in co-culture with other cell types such as BM-MSCs, ASCs, or fibroblasts in order to build 3D structures that anastomose with the host vasculature when grafted, thus improving vascularization of the construct [59,78-80]. Moreover it has also been shown that adipose tissue-derived ECs secrete soluble adipogenic factors $[81,82]$. Similarly, ASCs secrete factors during their adipogenic differentiation process that stimulate EC growth and motility in vitro as well as angiogenesis in vivo $[83,84]$. In this regard, a co-culture model including ASCs and ECs within 3D silk scaffolds showed the formation of endothelial tubes concomitant with the adipogenic differentiation of the ASCs [85].

\subsection{Biomolecules}

\subsubsection{Adipogenic Biomolecules}

A central issue in the preconditioning of MSCs for adipose tissue regeneration is the adipogenic induction before transplantation. In vitro adipogenic differentiation is characterized by growth arrest previous to the induction and expression of the adipogenic genes [86]. However, a cell-cell contact seems to be essential to direct terminal differentiation into mature adipocytes [62]. Studies in which adipogenic induction is performed prior to implantation of either ASCs or BM-MSCs demonstrate a clear advantage for in vivo adipose tissue development [70,87-89]. In the last year, $>20$ articles have been published for the in vitro adipogenic differentiation of mouse and human MSCs but generally, a 3-component cocktail is used. This cocktail comprises insulin, glucocorticoids (e.g. dexamethasone) and isobutyl methylxanthine (IBMX), a phosphodiesterase inhibitor that increases the levels of intracellular cAMP. Other molecules frequently found in adipogenic protocols are peroxisome proliferator-activated receptor gamma (PPAR $\gamma)$ agonists such thiazolidinediones (e.g. rosiglitazone, troglitazone) and indomethacin. The final concentrations of the different inductors in the media is highly variable, ranging from 0.2 to $12,000 \mathrm{nM}$ for Insulin, from 250 to $1000 \mathrm{nM}$ for Dexamethasone, and from 1 to $200 \mu \mathrm{M}$ for indomethacin [90].

\subsubsection{Neovasculogenic and Angiogenic Biomolecules}

Addition of angiogenic growth factors to engineered constructs is one of the strategies to improve neovasculogenesis and angiogenesis within the grafts. VEGF has long been established as the prime angiogenic molecule during development, adult physiology and pathology [91]. Hypoxic conditions induce the expression of angiogenic factors such as VEGF and leptin. VEGF is the most important endothelial cell growth factor necessary to initiate the formation of immature vessels by either vasculogenesis or angiogenic sprouting [92].

The hormone leptin is a $16-\mathrm{kDa}$ protein predominantly synthesized and secreted by adipocytes. Besides its main roles in the orchestration of the nutritional state and as a sensor of the availability of endogenous energy resources [93], several studies have confirmed that leptin- mediated auto- and paracrine stimulation of human fibroblasts [94] and keratinocytes $[95,96]$ accelerate wound healing $[97,98]$ and angiogenesis [99-102]. Thus, an important role of adipokines in regenerative conditions is generally acknowledged $[50,103]$. Leptin also modulates the expression of VEGF and plays a role in matrix remodelling, facilitating the angiogenic process and thus promoting neovascularization of the microenvironment [104].

In numerous studies basic fibroblast growth factor (bFGF) has been supplied to the media as a potent angiogenic factor, leading to vascularised adipose tissue [105-110]. Basic FGF induces an angiogenic response via a direct effect on endothelial cells, synergistically with VEGF $[111,112]$. Ordered orchestration by controlled release of the concentration of different biomolecules in the $3 \mathrm{D}$ constructs would permit successful neovasculogenesis and angiogenesis and, eventually, full and permanent take of the grafts [113-119].

In the last few years, new molecules have emerged as important regulators of angiogenesis and neovasculogenesis and their application for tissue engineering purposes is being considered [120-122].

\subsection{Materials}

Besides the appropriateness of cells and biomolecules, biomaterials are central components of tissue engineering strategies and play a pivotal role in the final outcome of the grafts [123].

The scaffolds are usually classified in two categories: porous or "hard" and injectable or "soft" scaffolds. The selection of one or the other type of scaffold depends on the strategy: hard scaffolds are used for predefined-shape 3D in vitro adipose tissue constructs (usually for large adipose tissue volume restoration) and soft matrices are used for in situ adipogenesis (for small volume loss).

\subsubsection{Hard Scaffolds for 3D in Vitro Adipose Tissue Engineering}

The ideal hard scaffolds should meet a long list of selection criteria: 1) They should support cell attachment, migration, cell-cell interactions, cell proliferation and differentiation; 2) They must be biocompatible; 3) They should also be biodegradable at a controlled rate -ideally one to match the rate of neotissue growth- to facilitate the integration of engineered tissue into the surrounding 
host tissue; 4) They must provide structural support for cells and neotissue formed in the scaffold during the initial stages post-implantation; 5) They should present interconnected pores to facilitate vessel growth and nutrient transport; 6) They should have versatile processing options to alter structure and morphology related to defect-specific needs [124,125].

Materials may be classified into natural and synthetic polymers. Among natural polymers hyaluronan [126], fibrin [127], collagen [128], gelatin [71], silk fibroin [72], chitosan-silk fibroin [129], alginate [130], decellularized placenta [131], extracellular matrix from adipose tissue [132-136] and combinations of them [137] have been very widely studied $[51,138,139]$.

The synthetic polymers include polyethyleneglycol (PEG) $[140,141]$, polytetrafluoroethylene [142], polyethylenene terephthalate [143], polyglycolic acid (PGA) [144], polylactic acid (PLA) and copolymers (PLGA) [16,109], polycaprolactone, polyurethanes, poly(ortho ester) and poly (anhydrides) $[11,51,86]$. Frequently, combinations are used such as heparin-conjugated fibrin hydrogels [145] and PEG-cross-linked heparin [146] among many others [147, 148]. Synthetic materials possess several drawbacks when compared to natural ones, such as the absence of intrinsic surface ligands for cell attachment and a potential impact of their degradation products on cell function [125]. Lately filamentous nanofibers are gaining importance, since their small diameter closely matches that of extracellular matrix fibers, allowing them to be used as biomimetic scaffolds [149-152].

Scaffold prevascularization strategies offer great promise to the field of adipose tissue engineering [79]. Prevascularization of matrices with the co-culture of endothelial cells and fibroblasts increased the ability of the constructs to create anastomoses with the host vasculature [153]. Once the capillary network was developed in vitro, the graft was implanted into the recipient. Natural scaffolding materials have extensively been used in the vascularisation of tissue engineering constructs including collagen, chitosan [154-156], decellularized extracellular matrix [157], and silk fibroin-fibrin [158,159]. The two most commonly used synthetic materials used for vascularization are PEG [160] and PLGA [160,161]. Although it would be highly desirable to control the kinetics of protein bioavailability through matrix release [162], clinical translation of systems capable of mimicking such naturally occurring processes is not foreseeable in the near future $[163,164]$.

\subsubsection{Soft Scaffolds for in Situ Neoadipogenesis}

Soft scaffolds permit the in situ generation of new adipose tissue. It may be achieved with the co-injection of growth factors, cells, tissue fillers or a combination of them. The ideal injectable material for soft tissue augmentation has possibly not yet been discovered, although some of them seem to be less risky than others [165]. In situ adipogenesis is a very appealing option to minimize scarring, risk of infections and eliminate the need for surgical interventions, thus reducing patient discomfort and intervention-related complications. Moreover, soft materials adapt to the shape of the cavity in which they are placed. However, they are only suitable for small volume replacements. Depending on their resorption rate, fillers are classified in three categories: resorbable within months, within years, and permanent fillers [166].

As seen for the hard scaffolds, soft scaffolds may also be classified as for their natural or synthetic origin. Derivatives of hydroxylapatite, PLA, collagen or hyaluronic acid are the most popular products used for in situ adipogenesis purposes. However, they only serve as temporary fillers and repeated injections are required to maintain the desired volume, due to the lack of a regenerative component [167]. Collagen has been on the market for the last two decades, and several collagenous products have been FDA-approved [168]. Alginate [169] or fibrin hydrogels have been extensively studied with promising results $[89,170,171]$. Other notable materials include polymethylmethacrylate, polyacrylamide and dextran [40].

Injectable micro and nanospheres are commonly used in combination with cells and growth factors for regenerative purposes [172,173]: PLGA microparticles carrying ASCs [174], BM-MSCs [175] or preadipocytes [176] are the most studied examples for adipose tissue engineering. Nevertheless, and due to their synthetic origin, their degradation products may cause $\mathrm{pH}$ variations that in turn lead to protein denaturing and impaired cell functionality [40]. Natural biopolymers in combination with cells such as collagenous microbeads with ASCs [177], chitosan microspheres with ASCs [178] or alginate microbeads [179] are alternatives with a safer degradation profile.

Finally, latest advances in biomaterial technology include new approaches such as 1) Temperature-sensitive hydrogels that are liquid at room temprature and gelify at $37^{\circ} \mathrm{C}[180,181]$; 2) $\mathrm{ECM}$ injectable powders shown to promote neoadipogenesis and angiogenesis in vivo [182], thus improving the results obtained with the autologous fat injection; 3) ECM microcarriers [183]; and 4) A photoactivated PEG- HA hydrogel filler that crosslinks in situ by a shining array of LEDS emitting light at a wavelength of $520 \mathrm{~nm}$. This filler can be massaged into the desired shape in situ before gelation through photoactivation [184].

\section{Concluding Remarks}

For the numerous adipose tissue engineering strategies here discussed, the most challenging task is repair and regeneration of large tissue defects. All the adipose tissue 
engineering studies conducted with cells have shown a positive effect when compared to a non-cell control, and thus cellular strategies are prevailing in the field. Cells may act in a paracrine manner, triggering a host response that stimulates the recruitment of endogenous stem cells to the site and promoting their differentiation along the required lineage $[66,185]$. At present most of the authors use MSCs for their adipose tissue engineering studies. ASCs and BM-MSCs are ideal starting populations for tissue engineering applications [51]. However, other authors suggest embryonic stem cells or germ cells as ideally suited for in vitro regenerative studies [186,187]. Risk/benefit balance of such pluripotent cell use should also be carefully considered.

Unlike other tissues, adipose tissue continuously undergoes expansion and regression and a constant adjustment of its capillary network is necessary. Therefore graft vascularization is a fundamental issue to be addressed when designing novel regenerative strategies. Although some authors have reported hypoxia-mediated angiogenesis in vivo [188], prevascularization of the grafts seems necessary for successful long-term outcome.

Despite the wide range of materials that have been intensively studied, every scaffold presents strengths and limitations and the ideal matrix for adipose tissue engineering surely has to be invented. Naturally-derived materials present many issues regarding pathogen transmission, or rapid volume lost. Synthetic materials often cause immunogenic reactions and integrate poorly with the host tissue. Acellular dermal matrices have been studied with promising results $[136,189]$. Several such dermal substitutes have already been approved by the FDA and are currently used in the clinics [190].

The in vitro development of $3 \mathrm{D}$ adipose tissue is also an invaluable tool for ex vivo studies on physiological disorders, metabolic diseases and drug testing. Monfort et al. speculated that BAT might be generated in their system due to the presence of the laminar cristae in the mitochondria reminiscent of that seen in human BAT [57, 191]. Although further evidence must be gathered to support this speculative hypothesis, the development of the BAT phenotype in vitro would be an interesting breakthrough for the study of its associated resistance to obesity and related metabolic disorders. Importantly, and regarding eventual grafting into patients, VEGF expression is much greater in BAT than in WAT $[192,193]$. This single fact makes BAT tissue highly attractive for regenerative purposes due to its intrinsic angiogenic properties.

The in vitro generation of $3 \mathrm{D}$ adipose tissue constructs led to the eventual development of complete trilayered engineered skin equivalents where the functional interaction of the adipose hypodermal layer with dermis and epidermis in vitro was evidenced [57,194]. Besides their usefulness for in vitro studies and drug testing, the ap- plication of trilayered skin constructs for in vivo grafting of full-thickness skin and its pharmaceutical development under GMP regulation could be considered [195].

In conclusion, adipose tissue engineering is rapidly advancing with the multidisciplinary collaborative work of stem cell biologists, biomaterial scientists, biomedical engineers and clinicians. It can be envisaged that these efforts will open innovative avenues for the development of a clinically relevant construct to support soft tissue repair and regeneration in the short term.

\section{Acknowledgements}

This work was financed by grants provided by Ministerio de Ciencia e Innovación [Proyecto Inv. Salud (PI10/02871) and INNPACTO (IPT-300000-2010-17) programs], Diputación Foral de Gipuzkoa (OF 53/2011 and OF 94/2008) and Gobierno Vasco (Dpto. de Industria SAIOTEK program-SAIO10-PE10BF01). A.I. was supported by the "Programa I3SNS" (CES09/015) from Instituto de Salud Carlos III and by Osakidetza-Servicio Vasco de Salud (Spain).

\section{REFERENCES}

[1] K. Karastergiou and V. Mohamed-Ali, "The Autocrine and Paracrine Roles of Adipokines," Molecular and Cellular Endocrinology, Vol. 318, No. 1-2, 2010, pp. 69-78. doi:10.1016/i.mce.2009.11.011

[2] S. C. Butterwith, "Regulators of Adipocyte Precursor Cells," Poultry Science, Vol. 76, No. 1, 1997, pp. 118-123.

[3] S. Cinti, "Reversible Physiological Transdifferentiation in the Adipose Organ," Proceedings of the Nutrition Society, Vol. 68, No. 4, 2009, pp. 340-349.

doi:10.1017/S0029665109990140

[4] H. Fujita, C. Asagami, Y. Oda, T. Mori and Y. Suetomi, "Electron Microscopic Studies of the Differentiation of Fat Cells in Human Fetal Skin," The Journal of Investigative Dermatology, Vol. 53, No. 2, 1969, pp. 122-139.

[5] L. Napolitano, "The Differentiation of White Adipose Cells. An Electron Microscope Study," The Journal of Cell Biology, Vol. 18, No. 3, 1963, pp. 663-679.

[6] M. P. Mattson, "Perspective: Does Brown Fat Protect against Diseases of Aging?" Ageing Research Reviews, Vol. 9, No. 1, 2010, pp. 69-76. doi:10.1016/j.arr.2009.11.004

[7] J. Nedergaard, T. Bengtsson and B. Cannon, "Three Years with Adult Human Brown Adipose Tissue," Annals of the New York Academy of Sciences, Vol. 1212, No. 1, 2010, pp. E20-E36.

[8] J. Nedergaard and B. Cannon, "The Changed Metabolic World with Human Brown Adipose Tissue: Therapeutic Visions," Cell Metabolism, Vol. 11, No. 4, 2010, pp. 268272. doi:10.1016/j.cmet.2010.03.007

[9] T. Purnak, E. Ozaslan, C. Efe and H. Sevimler, "A Missing Link in the Puzzle: Brown Adipose Tissue," Hepatology, Vol. 51, No. 4, 2010, pp. 1470-1471. 
doi:10.1002/hep.23559

[10] Y.-H. Tseng, A. M. Cypess and C. R. Kahn, "Cellular Bioenergetics as a Target for Obesity Therapy," Nature Reviews Drug Discovery, Vol. 9, No. 6, 2010, pp. 465482. doi: $10.1038 / \mathrm{nrd} 3138$

[11] E. Carletti, A. Motta and C. Migliaresi, "Scaffolds for Tissue Engineering and 3D Cell Culture," Methods in Molecular Biology, Vol. 695, 2011, pp. 17-39.

[12] Neuber, "Fat Trasplantation," Verhandlungen Der Deutschen Gesellschaft Für Chirurgie, 1893.

[13] E. Lexer, "Freie Fettransplantation," Deutsche Medizinische Wochenschrift, Vol. 36, 1910, p. 640.

[14] Rehn, "Die Fettransplantaton," Archiv Für Klinische Chirurgie, Vol. 98, 1912, p. 1.

[15] L. A. Peer, "The Neglected Free Fat Graft," Plastic \& Reconstructive Surgery, Vol. 18, No. 4, 1956, pp. 233-250.

[16] C. W. Patrick Jr., P. B. Chauvin, J. Hobley and G. P. Reece, "Preadipocyte Seeded PLGA Scaffolds for Adipose Tissue Engineering," Tissue Engineering, Vol. 5, No. 2, 1999, pp. 139-151. doi:10.1089/ten.1999.5.139

[17] C. W. Patrick Jr., B. Zheng, C. Johnston and G. P. Reece, "Long-Term Implantation of Preadipocyte-Seeded PLGA Scaffolds," Tissue Engineering, Vol. 8, No. 2, 2002, pp. 283-293. doi:10.1089/107632702753725049

[18] B. Sommer and G. Sattler, "Current Concepts of Fat Graft Survival: Histology of Aspirated Adipose Tissue and Review of the Literature," Dermatologic Surgery, Vol. 26, No. 12, 2000, pp. 1159-1166. doi:10.1046/j.1524-4725.2000.00278.x

[19] J.-H. Choi, J. M. Gimble, K. Lee, K. G. Marra, J. P. Rubin, J. J. Yoo, G. Vunjak-Novakovic and D. L. Kaplan, "Adipose Tissue Engineering for Soft Tissue Regeneration," Tissue Engineering Part B: Reviews, Vol. 16, No. 4, 2010, pp. 413-426. doi:10.1089/ten.teb.2009.0544

[20] L. C. Clauser, R. Tieghi, M. Galie, F. Carinci, et al., "Structural Fat Grafting: Facial Volumetric Restoration in Complex Reconstructive Surgery," Journal of Craniofacial Surgery, Vol. 22, No. 5, 2011, pp. 1695-1701. doi:10.1097/SCS.0b013e31822e5d5e

[21] B. S. Korn, D. O. Kikkawa, S. R. Cohen, M. Hartstein and C. C. Annunziata, "Treatment of Lower Eyelid Malposition with Dermis Fat Grafting," Ophthalmology, Vol. 115, No. 4, 2008, pp. 744-751.

[22] R. Rauso, G. Tartaro, N. Freda, A. Rusciani and G. Curinga, "A Facial Marker in Facial Wasting Rehabilitation," The Journal of Drugs in Dermatology, Vol. 11, No. 2, 2012, pp. 202-208.

[23] M. Wetterau, C. Szpalski, A. Hazen and S. M. Warren, "Autologous Fat Grafting and Facial Reconstruction," Journal of Craniofacial Surgery, Vol. 23, No. 1, 2012, pp. 315-318. doi:10.1097/SCS.0b013e318241e1de

[24] J. C. Alencar, S. H. Andrade, S. G. Pessoa and I. S. Dias, "Autologous Fat Transplantation for the Treatment of Progressive Hemifacial Atrophy (Parry-Romberg Syndrome: Case Report and Review of Medical Literature)," Anais Brasileiros De Dermatologia, Vol. 86, No. 4, 2011, pp. S85-S88. doi:10.1590/S0365-05962011000700022
[25] J.-H. Jun, H.-Y. Kim, H.-J. Jung, W.-J. Lee, S.-J. Lee, D.-W. Kim, M.-B. Kim and B.-S. Kim, "Parry-Romberg Syndrome with En Coup de Sabre," Annals of Dermatology, Vol. 23, No. 3, 2011, pp. 342-347. doi:10.5021/ad.2011.23.3.342

[26] M. V. Karaaltin, A. C. Akpinar, S. Baghaki and F. Akpinar, "Treatment of 'En Coup De Sabre' Deformity with Adipose-Derived Regenerative Cell-Enriched Fat Graft," Journal of Craniofacial Surgery, Vol. 23, No. 2, 2012, pp. e103-e105. doi:10.1097/SCS.0b013e3182418ce8

[27] R. Guijarro-Martínez, L. M. Alba, M. M. Mateo, M. P. Torres and J. V. P. Gil, "Autologous Fat Transfer to the Cranio-Maxillofacial Region: Updates and Controversies," Journal of Cranio-Maxillo-Facial Surgery, Vol. 39, No. 5, 2011, pp. 359-363. doi:10.1016/j.jcms.2010.07.004

[28] C. W. Chan, S. J. McCulley and R. D. Macmillan, "Autologous Fat Transfer-A Review of the Literature with a Focus on Breast Cancer Surgery," Journal of Plastic, Reconstructive \& Aesthetic Surgery, Vol. 61, No. 12, 2008, pp. 1438-1448. doi:10.1016/j.bjps.2008.08.006

[29] D. ELFadl, V. Garimella, T. K. Mahapatra, P. L. McManus and P. J. Drew, "Lipomodelling of the Breast: A Review," The Breast, Vol. 19, No. 3, 2010, pp. 202-209. doi:10.1016/j.breast.2010.02.009

[30] H. Mizuno and H. Hyakusoku, "Fat Grafting to the Breast and Adipose-Derived Stem Cells: Recent Scientific Consensus and Controversy," Aesthetic Surgery Journal, Vol. 30, No. 3, 2010, pp. 381-387. doi:10.1177/1090820X10373063

[31] M. Klinger, F. Caviggioli, V. Vinci, A. Salval and F. Villani, "Treatment of Chronic Posttraumatic Ulcers Using Autologous Fat Graft," Plastic \& Reconstructive Surgery, Vol. 126, No. 3, 2010, pp. 154e-155e. doi:10.1097/PRS.0b013e3181e3b585

[32] R. A. Glasgold, S. M. Lam and M. J. Glasgold, "Facial Fat Grafting: The New Paradigm," Archives of Facial Plastic Surgery, Vol. 10, No. 6, 2008, pp. 417-418. doi:10.1001/archfaci.10.6.417

[33] M. Glashofer and N. Lawrence, "Fat Transplantation for Treatment of the Senescent Face," Dermatologic Therapy, Vol. 19, No. 3, 2006, pp. 169-176. doi:10.1111/j.1529-8019.2006.00071.x

[34] S. Kranendonk and S. Obagi, "Autologous Fat Transfer for Periorbital Rejuvenation: Indications, Technique, and Complications," Dermatologic Surgery, Vol. 33, No. 5, 2007, pp. 572-578. doi:10.1111/j.1524-4725.2007.33116.x

[35] B. Nicareta, L. H. Pereira, A. Sterodimas and Y. G. Illouz, "Autologous Gluteal Lipograft," Aesthetic Plastic Surgery, Vol. 35, No. 2, 2011, pp. 216-224. doi:10.1007/s00266-010-9590-y

[36] C. J. Salgado, J. C. Tang and A. E. Desrosiers, "Use of Dermal Fat Graft for Augmentation of the Labia Majora," Journal of Plastic, Reconstructive \& Aesthetic Surgery, Vol. 65, No. 2, 2012, pp. 267-270. doi:10.1016/i.bjps.2011.07.010

[37] D. E. Panfilov, "Augmentative Phalloplasty," Aesthetic Plastic Surgery, Vol. 30, No. 2, 2006, pp. 183-197. doi:10.1007/s00266-004-0153-y 
[38] Y. Har-Shai, E. Lindenbaum, O. Ben-Itzhak and B. Hirshowitz, "Large Liponecrotic Pseudocyst Formation Following Cheek Augmentation by Fat Injection," Aesthetic Plastic Surgery, Vol. 20, No. 5, 1996, pp. 417-419. doi:10.1007/BF02390317

[39] G. F. Maillard, "Liponecrotic Cysts after Augmentation Mammaplasty with Fat Injections," Aesthetic Plastic Surgery, Vol. 18, No. 4, 1994, pp. 405-406. doi:10.1007/BF00451348

[40] D. A. Young and K. L. Christman, "Injectable Biomaterials for Adipose Tissue Engineering," Biomedical Materials, Vol. 7, No. 2, 2012, Article ID: 024104. doi:10.1088/1748-6041/7/2/024104

[41] J. D. Meier, R. A. Glasgold and M. J. Glasgold, "Autologous Fat Grafting: Long-Term Evidence of Its Efficacy in Midfacial Rejuvenation," Archives of Facial Plastic Surgery, Vol. 11, No. 1, 2009, pp. 24-28. doi:10.1001/archfacial.2008.518

[42] T. Tiryaki, N. Findikli and D. Tiryaki, "Staged Stem CellEnriched Tissue (Set) Injections for Soft Tissue Augmentation in Hostile Recipient Areas: A Preliminary Report," Aesthetic Plastic Surgery, Vol. 35, No. 6, 2011, pp. 965-971. doi:10.1007/s00266-011-9716-X

[43] P. S. Wiggenhauser, D. F. Müller, F. P. W. Melchels, J. T. Egaña, K. Storck, H. Mayer, P. Leuthner, D. Skodacek, U. Hopfner, H. G. Machens, R. Staudenmaier and J. T. Schantz, "Engineering of Vascularized Adipose Constructs," Cell and Tissue Research, Vol. 347, No. 3, 2012, pp. 747-757. doi:10.1007/s00441-011-1226-2

[44] K. Yoshimura, K. Sato, N. Aoi, M. Kurita, T. Hirohi and K. Harii, "Cell-Assisted Lipotransfer for Cosmetic Breast Augmentation: Supportive Use of Adipose-Derived Stem/ Stromal Cells," Aesthetic Plastic Surgery, Vol. 32, No. 1, 2008, pp. 48-55. doi:10.1007/s00266-007-9019-4

[45] S. H. Jeong, S. K. Han and W. K. Kim, "Soft Tissue Augmentation Using in vitro Differentiated Adipocytes: A Clinical Pilot Study," Dermatologic Surgery, Vol. 37, No. 6, 2011, pp. 760-767.

[46] M. Kim, I. Kim, S. K. Lee, S. I. Bang and S. Y. Lim, "Clinical Trial of Autologous Differentiated Adipocytes from Stem Cells Derived from Human Adipose Tissue," Dermatologic Surgery, Vol. 37, No. 6, 2011, pp. 750-759. doi:10.1111/j.1524-4725.2011.01765.x

[47] J. H. Rosing, G. Wong, M. S. Wong, D. Sahar, T. R. Stevenson and L. L. Q. Pu, "Autologous Fat Grafting for Primary Breast Augmentation: A Systematic Review," Aesthetic Plastic Surgery, Vol. 35, No. 5, 2011, pp. 882890. doi:10.1007/s00266-011-9691-2

[48] C. J. Tabit, G. C. Slack, K. Fan, D. C. Wan and J. P. Bradley, "Fat Grafting versus Adipose-Derived Stem Cell Therapy: Distinguishing Indications, Techniques, and Outcomes," Aesthetic Plastic Surgery, Vol. 36, No. 3, 2012, pp. 704-713.

[49] K.-M. Moon, Y.-H. Park, J.-S. Lee, Y.-B. Chae, M.-M. Kim, D.-S. Kim, B.-W. Kim, S.-W. Nam and J.-H. Lee, "The Effect of Secretory Factors of Adipose-Derived Stem Cells on Human Keratinocytes," International Journal of Molecular Sciences, Vol. 13, No. 1, 2012, pp. 1239-1257. doi:10.3390/ijms13011239
[50] A. Murad, A. K. Nath, S. T. Cha, E. Demir, J. FloresRiveros and M. R. Sierra-Honigmann, "Leptin Is an Autocrine/Paracrine Regulator of Wound Healing," The FASEB Journal, Vol. 17, No. 13, 2003, pp. 1895-1897.

[51] P. Bauer-Kreisel, A. Goepferich and T. Blunk, "CellDelivery Therapeutics for Adipose Tissue Regeneration," Advanced Drug Delivery Reviews, Vol. 62, No. 7-8, 2010, pp. 798-813. doi:10.1016/j.addr.2010.04.003

[52] F. O. Adebonojo, "Studies on Human Adipose Cells in Culture: Relation of Cell Size and Multiplication to Donor Age," Yale Journal of Biology \& Medicine, Vol. 48, No. 1, 1975, pp. 9-16.

[53] G. Entenmann and H. Hauner, "Relationship between Replication and Differentiation in Cultured Human Adipocyte Precursor Cells," American Journal of Physiology-Cell Physiology, Vol. 270, No. 4, 1996, pp. C1011C1016.

[54] E. Sonoda, S. Aoki, K. Uchihashi, H. Soejima, S. Kanaji, K. Izuhara, S. Satoh, N. Fujitani, H. Sugihara and S. Toda, "A New Organotypic Culture of Adipose Tissue Fragments Maintains Viable Mature Adipocytes for a Long Term, Together with Development of Immature Adipocytes and Mesenchymal Stem Cell-Like Cells," Endocrinology, Vol. 149, No. 10, 2008, pp. 4794-4798. doi:10.1210/en.2008-0525

[55] H. H. Zhang, S. Kumar, A. H. Barnett and M. C. Eggo, "Ceiling Culture of Mature Human Adipocytes: Use in Studies of Adipocyte Functions," Journal of Endocrinology, Vol. 164, No. 2, 2000, pp. 119-128. doi:10.1677/joe.0.1640119

[56] C. W. Patrick, Jr., "Tissue Engineering Strategies for Adipose Tissue Repair," The Anatomical Record, Vol. 263, No. 4, 2001, pp. 361-366. doi:10.1002/ar.1113

[57] A. Monfort, M. Soriano-Navarro, J. M. Garcia-Verdugo, and A. Izeta, "Production of Human Tissue-Engineered Skin Trilayer on a Plasma-Based Hypodermis," Journal of Tissue Engineering and Regenerative Medicine, 2012. doi: $10.1002 /$ term.548

[58] I. Beloqui, A. Monfort, J. M. Santos, F. J. Legorburu and A. G. Martin, "Breast Reconstruction Using Stem Cells and Engineered Biomaterials," Recent Patents in Regenerative Medicine, Vol. 2, 2012, pp. 114-124.

[59] A. Wilson, P. E. Butler and A. M. Seifalian, "AdiposeDerived Stem Cells for Clinical Applications: A Review," Cell Proliferation, Vol. 44, No. 1, 2011, pp. 86-98. doi:10.1111/j.1365-2184.2010.00736.x

[60] B. M. Strem, K. C. Hicok, M. Zhu, I. Wulur, Z. Alfonso, R. E. Schreiber, J. K. Fraser and M. H. Hedrick, "Multipotential Differentiation of Adipose Tissue-Derived Stem Cells," The Keio Journal of Medicine, Vol. 54, No. 3, 2005, pp. 132-141. doi:10.2302/kjm.54.132

[61] I. Cárcamo-Orive, A. Gaztelumendi, J. Delgado, N. Tejados, A. Dorronsoro, J. Fernandez-Rueda, D. J. Pennington and C. Trigueros, "Regulation of Human Bone Marrow Stromal Cell Proliferation and differentiation Capacity by Glucocorticoid Receptor and AP-1 Crosstalk," Journal of Bone and Mineral Research, Vol. 25, No. 10, 2010, pp. 2115-2125. doi:10.1002/jbmr.120

[62] I. Carcamo-Orive, N. Tejados, J. Delgado, A. Gaztelu- 
mendi, D. Otaegui, V. Lang and C. Trigueros, "ERK2 Protein Regulates the Proliferation of Human Mesenchymal Stem Cells without Affecting Their Mobilization and Differentiation Potential," Experimental Cell Research, Vol. 314, No. 8, 2008, pp. 1777-1788. doi:10.1016/j.yexcr.2008.01.020

[63] M. Konno, T. S. Hamazaki, S. Fukuda, M. Tokuhara, H. Uchiyama, H. Okazawa, H. Okochi and M. Asashima, "Efficiently Differentiating Vascular Endothelial Cells from Adipose Tissue-Derived Mesenchymal Stem Cells in Serum-Free Culture," Biochemical and Biophysical Research Communications, Vol. 400, No. 4, 2010, pp. 461465. doi:10.1016/j.bbrc.2010.08.029

[64] E. Lombardo, O. DelaRosa, P. Mancheño-Corvo, R. Menta, C. Ramírez and D. Büscher, "Toll-Like ReceptorMediated Signaling in Human Adipose-Derived Stem Cells: Implications for Immunogenicity and Immunosuppressive Potential," Tissue Engineering Part A, Vol. 15, No. 7, 2009, pp. 1579-1589. doi: $10.1089 /$ ten.tea.2008.0340

[65] C. Nakanishi, N. Nagaya, S. Ohnishi, K. Yamahara, S. Takabatake, T. Konno, K. Hayashi, M. A. Kawashiri, T. Tsubokawa and M. Yamagishi, "Gene and Protein Expression Analysis of Mesenchymal Stem Cells Derived From Rat Adipose Tissue and Bone Marrow," Circulation Journal, Vol. 75, No. 9, 2011, pp. 2260-2268. doi:10.1253/circj.CJ-11-0246

[66] G. E. Kilroy, S. J. Foster, X. Wu, J. Ruiz, S. Sherwood, A. Heifetz, J. W. Ludlow, D. M. Stricker, S. Potiny, P. Green, Y. D. Halvorsen, B. Cheatham, R. W. Storms and J. M. Gimble, "Cytokine Profile of Human AdiposeDerived Stem Cells: Expression of Angiogenic, Hematopoietic, and Pro-Inflammatory Factors," Journal of Cellular Physiology, Vol. 212, No. 3, 2007, pp. 702-709. doi:10.1002/jcp. 21068

[67] B. Labbé, G. Marceau-Fortier and J. Fradette, "Cell Sheet Technology for Tissue Engineering: The Self-Assembly Approach Using Adipose-Derived Stromal Cells," Methods in Molecular Biology, Vol. 702, No. 4, 2011, pp. 429441.

[68] M. Vallee, J. F. Cote and J. Fradette, "Adipose-Tissue Engineering: Taking Advantage of the Properties of Human Adipose-Derived Stem/Stromal Cells," Pathologie Biologie, Vol. 57, No. 4, 2009, pp. 309-317. doi:10.1016/j.patbio.2008.04.010

[69] M. Vermette, V. Trottier, V. Ménard, L. Saint-Pierre, A. Roy and J. Fradette, "Production of a New Tissue-Engineered Adipose Substitute from Human Adipose-Derived Stromal Cells," Biomaterials, Vol. 28, No. 18, 2007, pp. 2850-2860. doi:10.1016/j.biomaterials.2007.02.030

[70] L. Hong, I. A. Peptan, A. Colpan and J. L. Daw, "Adipose Tissue Engineering by Human Adipose-Derived Stromal Cells," Cells Tissues Organs, Vol. 183, No. 3, 2006, pp. 133-140. doi:10.1159/000095987

[71] S. D. Lin, S. H. Huang, Y. N. Lin, S. H. Wu, H. W. Chang, T. M. Lin, C. Y. Chai and C. S. Lai, "Engineering Adipose Tissue from Uncultured Human Adipose Stromal Vascular Fraction on Collagen Matrix and Gelatin Sponge Scaffolds," Tissue Engineering Part A, Vol. 17, No. 11-12, 2011, pp. 1489-1498. doi:10.1089/ten.tea.2010.0688

[72] J. R. Mauney, T. Nguyen, K. Gillen, C. Kirker-Head, J. M. Gimble and D. L. Kaplan, "Engineering Adipose-Like Tissue in Vitro and in Vivo Utilizing Human Bone Marrow and Adipose-Derived Mesenchymal Stem Cells with Silk Fibroin 3D Scaffolds," Biomaterials, Vol. 28, No. 35, 2007, pp. 5280-5290. doi:10.1016/j.biomaterials.2007.08.017

[73] M. Radisic, H. Park, F. Chen, J. E. Salazar-Lazzaro, Y. Wang, R. Dennis, R. Langer, L. E. Freed and G. VunjakNovakovic, "Biomimetic Approach to Cardiac Tissue Engineering: Oxygen Carriers and Channeled Scaffolds," Tissue Engineering, Vol. 12, No. 8, 2006, pp. 2077-2091. doi:10.1089/ten.2006.12.2077

[74] M. Radisic, J. Malda, E. Epping, W. Geng, R. Langer and G. Vunjak-Novakovic, "Oxygen Gradients Correlate with Cell Density and Cell Viability in Engineered Cardiac Tissue," Biotechnology and Bioengineering, Vol. 93, No. 2, 2006, pp. 332-343. doi:10.1002/bit.20722

[75] E. C. Novosel, C. Kleinhans and P. J. Kluger, "Vascularization Is the Key Challenge in Tissue Engineering," Advanced Drug Delivery Reviews, Vol. 63, No. 4-5, 2011, pp. 300-311. doi:10.1016/j.addr.2011.03.004

[76] J. X. Sun, Y. L. Wang, Z. Y. Qian and C. B. Hu, "An Approach to Architecture 3D Scaffold with Interconnective Microchannel Networks Inducing Angiogenesis for Tissue Engineering," Journal of Materials Science: Materials in Medicine, Vol. 22, No. 11, 2011, pp. 2565-2571. doi:10.1007/s10856-011-4426-0

[77] Z. Lokmic and G. M. Mitchell, "Engineering the Microcirculation," Tissue Engineering Part B: Reviews, Vol. 14, No. 1, 2008, pp. 87-103. doi:10.1089/teb.2007.0299

[78] V. Hudon, F. Berthod, A. F. Black, O. Damour, L. Germain and F. A. Auger, "A Tissue-Engineered Endothelialized Dermis to Study the Modulation of Angiogenic and Angiostatic Molecules on Capillary-Like Tube Formation in Vitro," British Journal of Dermatology, Vol. 148, No. 6, 2003, pp. 1094-1104.

doi:10.1046/j.1365-2133.2003.05298.x

[79] F. Verseijden, S. J. Posthumus-van Sluijs, E. Farrell, J. W. van Neck, S. E. R. Hovius, S. O. P. Hofer and G. J. V. M. van Osch, "Prevascular Structures Promote Vascularization in engineered Human Adipose Tissue Constructs upon Implantation," Cell Transplantation, Vol. 19, No. 8, 2010, pp. 1007-1020. doi:10.3727/096368910X492571

[80] F. Verseijden, S. J. Posthumus-van Sluijs, P. Pavljasevic, S. O. P. Hofer, G. J. V. M. van Osch and E. Farrell, "Adult Human Bone Marrow- and Adipose Tissue-Derived Stromal Cells Support the Formation of Prevascular-Like Structures from Endothelial Cells in vitro," Tissue Engineering Part A, Vol. 16, No. 1, 2010, pp. 101114. doi:10.1089/ten.tea.2009.0106

[81] L. J. Hutley, A. C. Herington, W. Shurety, C. Cheung, D. A. Vesey, D. P. Cameron and J. B. Prins, "Human Adipose Tissue Endothelial Cells Promote Preadipocyte Proliferation," American Journal of Physiology-Endocrinology and Metabolism, Vol. 281, No. 5, 2001, pp. E1037E1044.

[82] J. Borges, M. C. Müller, A. Momeni, G. B. Stark and N. 
Torio-Padron, "In vitro Analysis of the Interactions between Preadipocytes and Endothelial Cells in a 3D Fibrin Matrix," Minimally Invasive Therapy and Allied Technologies, Vol. 16, No. 3, 2007, pp. 141-148. doi:10.1080/13645700600935398

[83] D. E. Dobson, A. Kambe, E. Block, T. Dion, H. Lu, J. J. Castellot, Jr. and B. M. Spiegelman, "1-Butyryl-Glycerol: A Novel Angiogenesis Factor Secreted by Differentiating Adipocytes," Cell, Vol. 61, No. 2, 1990, pp. 223-230. doi:10.1016/0092-8674(90)90803-M

[84] J. J. Castellot Jr., M. J. Karnovsky and B. M. Spiegelman, "Differentiation-Dependent Stimulation of Neovascularization and Endothelial Cell Chemotaxis by 3T3 Adipocytes," Proceedings of the National Academy of Sciences of the United States of America, Vol. 79, No. 18, 1982, pp. 5597-5601. doi:10.1073/pnas.79.18.5597

[85] J. H. Kang, J. M. Gimble and D. L. Kaplan, "In Vitro 3D Model for Human Vascularized Adipose Tissue," Tissue Engineering Part A, Vol. 15, No. 8, 2009, pp. 2227-2236. doi: $10.1089 /$ ten.tea.2008.0469

[86] L. Flynn and K. A. Woodhouse, "Adipose Tissue Engineering with Cells in Engineered Matrices," Organogenesis, Vol. 4, No. 4, 2008, pp. 228-235. doi:10.4161/org.4.4.7082

[87] Y. Itoi, M. Takatori, H. Hyakusoku and H. Mizuno, "Comparison of Readily Available Scaffolds for Adipose Tissue Engineering Using Adipose-Derived Stem Cells," Journal of Plastic, Reconstructive \& Aesthetic Surgery, Vol. 63, No. 5, 2010, pp. 858-864. doi:10.1016/j.bjps.2009.01.069

[88] H. Mizuno, Y. Itoi, S. Kawahara, R. Ogawa, S. Akaishi, and H. Hyakusoku, "In Vivo Adipose Tissue Regeneration by Adipose-Derived Stromal Cells Isolated from GFP Transgenic Mice," Cells Tissues Organs, Vol. 187, No. 3, 2008, pp. 177-185. doi:10.1159/000110805

[89] S.-W. Cho, I. Kim, S.-H. Kim, J.-W. Rhie, C.-Y. Choi and B.-S. Kim, "Enhancement of Adipose Tissue Formation by Implantation of Adipogenic-Differentiated Preadipocytes," Biochemical and Biophysical Research Communications, Vol. 345, No. 2, 2006, pp. 588-594. doi:10.1016/j.bbrc.2006.04.089

[90] M. A. Scott, V. T. Nguyen, B. Levi and A. W. James, "Current Methods of Adipogenic Differentiation of Mesenchymal Stem Cells," Stem Cells and Development, Vol. 20, No. 10, 2011, pp. 1793-1804. doi:10.1089/scd.2011.0040

[91] T. Tammela, B. Enholm, K. Alitalo and K. Paavonen, "The Biology of Vascular Endothelial Growth Factors," Cardiovascular Research, Vol. 65, No. 3, 2005, pp. 550563. doi:10.1016/j.cardiores.2004.12.002

[92] G. J. Hausman and R. L. Richardson, "Adipose Tissue Angiogenesis," Journal of Animal Science, Vol. 82, No. 3, 2004, pp. 925-934.

[93] L. Gautron and J. K. Elmquist, "Sixteen Years and Counting: An Update on Leptin in Energy Balance," The Journal of Clinical Investigation, Vol. 121, No. 6, 2011, pp. 2087-2093. doi:10.1172/JCI45888

[94] T. Ezure and S. Amano, "Adiponectin and Leptin UpRegulate Extracellular Matrix Production by Dermal Fi- broblasts," Biofactors, Vol. 31, No. 3-4, 2007, pp. 229236. doi:10.1002/biof.5520310310

[95] B. Poeggeler, C. Schulz, M. A. Pappolla, E. Bodo, S. Tiede, H. Lehnert and R. Paus, "Leptin and the Skin: A New Frontier," Experimental Dermatology, Vol. 19, No. 1, 2010, pp. 12-18. doi:10.1111/j.1600-0625.2009.00930.x

[96] B. Stallmeyer, H. Kämpfer, M. Podda, R. Kaufmann, J. Pfeilschifter and S. Frank, "A Novel Keratinocyte Mitogen: Regulation of Leptin and Its Functional Receptor in Skin Repair," Journal of Investigative Dermatology, Vol. 117 , No. 1, 2001, pp. 98-105. doi:10.1046/j.0022-202x.2001.01387.x

[97] J. Klein, P. A. Permana, M. Owecki, G. N. Chaldakov, M. Bohm, G. Hausman, C. M. Lapiere, P. Atanassova, J. Sowinski, M. Fasshauer, D. B. Hausman, E. Maquoi, A. B. Tonchev, V. N. Peneva, K. P. Vlachanov, M. Fiore, L. Aloe, A. Slominski, C. L. Reardon, T. J. Ryan, C. M. Pond and T. J. Ryan, "What Are Subcutaneous Adipocytes Really Good for?” Experimental Dermatology, Vol. 16, No. 1, 2007, pp. 45-70.

[98] B. Wang, I. S. Wood and P. Trayhurn, "Hypoxia Induces Leptin Gene Expression and Secretion in Human Preadipocytes: Differential Effects of Hypoxia on Adipokine Expression by Preadipocytes," Journal of Endocrinology, Vol. 198, No. 1, 2008, pp. 127-134. doi:10.1677/JOE-08-0156

[99] A. Bouloumié, H. C. Drexler, M. Lafontan and R. Busse, "Leptin, the Product of $\mathrm{Ob}$ Gene, Promotes Angiogenesis," Circulation Research, Vol. 83, No. 10, 1998, pp. 1059-1066. doi:10.1161/01.RES.83.10.1059

[100] R. Cao, E. Brakenhielm, C. Wahlestedt, J. Thyberg and Y. Cao, "Leptin Induces Vascular Permeability and Synergistically Stimulates Angiogenesis with FGF-2 and VEGF," Proceedings of the National Academy of Sciences of the United States of America, Vol. 98, No. 11, 2001, pp. 6390-6395. doi:10.1073/pnas.101564798

[101] I. Liapaki, S. Anagnostoulis, A. Karayiannakis, D. Korkolis, M. Labropoulou, A. Matarasso and C. Simopoulos, "Burn Wound Angiogenesis Is Increased by Exogenously Administered Recombinant Leptin in Rats," Acta Cirurgica Brasileira, Vol. 23, No. 2, 2008, pp. 118124. doi:10.1590/S0102-86502008000200002

[102] I. E. Liapakis, S. Anagnostoulis, A. J. Karayiannakis, D. P. Korkolis, M. Lambropoulou, E. Arnaud and C. E. Simopoulos, "Recombinant Leptin Administration Improves Early Angiogenesis in Full-Thickness Skin Flaps: An Experimental Study," In Vivo, Vol. 22, No. 2, 2008, pp. 247-252.

[103] S. Frank, B. Stallmeyer, H. Kampfer, N. Kolb and J. Pfeilschifter, "Leptin Enhances Wound Re-Epithelialization and Constitutes a Direct Function of Leptin in Skin Repair," The Journal of Clinical Investigation, Vol. 106, No. 4, 2000, pp. 501-509. doi:10.1172/JCI9148

[104] H. Y. Park, H. M. Kwon, H. J. Lim, B. K. Hong, J. Y. Lee, B. E. Park, Y. Jang, S. Y. Cho and H. S. Kim, "Potential Role of Leptin in Angiogenesis: Leptin Induces Endothelial Cell Proliferation and Expression of Matrix Metalloproteinases in vivo and in vitro," Experimental \& Molecular Medicine, Vol. 33, No. 2, 2001, pp. 95-102. 
[105] N. Kawaguchi, K. Toriyama, E. Nicodemou-Lena, K. Inou, S. Torii and Y. Kitagawa, "De Novo Adipogenesis in Mice at the Site of Injection of Basement Membrane and Basic Fibroblast Growth Factor," Proceedings of the National Academy of Sciences of the United States of America, Vol. 95, No. 3, 1998, pp. 1062-1066. doi:10.1073/pnas.95.3.1062

[106] Y. Kimura, M. Ozeki, T. Inamoto and Y. Tabata, "Time Course of de Novo Adipogenesis in Matrigel by Gelatin Microspheres Incorporating Basic Fibroblast Growth Factor," Tissue Engineering, Vol. 8, No. 4, 2002, pp. 603613. doi:10.1089/107632702760240526

[107] Y. Kimura, M. Ozeki, T. Inamoto and Y. Tabata, "Adipose Tissue Engineering Based on Human Preadipocytes Combined with Gelatin Microspheres Containing Basic Fibroblast Growth Factor," Biomaterials, Vol. 24, No. 14, 2003, pp. 2513-2521. doi:10.1016/S0142-9612(03)00049-8

[108] Y. Kimura, W. Tsuji, H. Yamashiro, M. Toi, T. Inamoto and Y. Tabata, "In Situ Adipogenesis in Fat Tissue Augmented by Collagen Scaffold with Gelatin Microspheres Containing Basic Fibroblast Growth Factor," Journal of Tissue Engineering and Regenerative Medicine, Vol. 4, No. 1, 2010, pp. 55-61.

[109] M. Neubauer, M. Hacker, P. Bauer-Kreisel, B. Weiser, C. Fischbach, M. B. Schulz, A. Goepferich and T. Blunk, "Adipose Tissue Engineering Based on Mesenchymal Stem Cells and Basic Fibroblast Growth Factor in Vitro," Tissue Engineering, Vol. 11, No. 11-12, 2005, pp. 18401851. doi:10.1089/ten.2005.11.1840

[110] Y. Tabata, M. Miyao, T. Inamoto, T. Ishii, Y. Hirano, Y. Yamaoki and Y. Ikada, "De Novo Formation of Adipose Tissue by Controlled Release of Basic Fibroblast Growth Factor," Tissue Engineering, Vol. 6, No. 3, 2000, pp. 279289. doi:10.1089/10763270050044452

[111] M. S. Pepper, N. Ferrara, L. Orci and R. Montesano, "Potent Synergism between Vascular Endothelial Growth Factor and Basic Fibroblast Growth Factor in the Induction of Angiogenesis in Vitro," Biochemical and Biophysical Research Communications, Vol. 189, No. 2, 1992, pp. 824-831. doi:10.1016/0006-291X(92)92277-5

[112] C. Lieu, J. Heymach, M. Overman, H. Tran and S. Kopetz, "Beyond VEGF: Inhibition of the Fibroblast Growth Factor Pathway and Antiangiogenesis," Clinical Cancer Research, Vol. 17, No. 19, 2011, pp. 6130-6139. doi:10.1158/1078-0432.CCR-11-0659

[113] A. Arkudas, J. Tjiawi, O. Bleiziffer, L. Grabinger, E. Polykandriotis, J. P. Beier, M. Sturzl, R. E. Horch and U. Kneser, "Fibrin Gel-Immobilized VEGF and bFGF Efficiently Stimulate Angiogenesis in the AV Loop Model," Molecular Medicine, Vol. 13, No. 9-10, 2007, pp. 480487. doi:10.2119/2007-00057.Arkudas

[114] R. R. Chen, E. A. Silva, W. W. Yuen, A. A. Brock, C. Fischbach, A. S. Lin, R. E. Guldberg and D. J. Mooney, "Integrated Approach to Designing Growth Factor Delivery Systems," The FASEB Journal, Vol. 21, No. 14, 2007, pp. 3896-3903. doi:10.1096/fj.06-7873com

[115] A. des Rieux, B. Ucakar, B. P. Mupendwa, D. Colau, O. Feron, P. Carmeliet and V. Préat, "3D Systems Deliver- ing VEGF to Promote Angiogenesis for Tissue Engineering," Journal of Controlled Release, Vol. 150, No. 3, 2011, pp. 272-278. doi:10.1016/i.jconrel.2010.11.028

[116] J. S. Golub, Y. T. Kim, C. L. Duvall, R. V. Bellamkonda, D. Gupta, A. S. Lin, D. Weiss, W. Robert Taylor and R. E. Guldberg, "Sustained VEGF Delivery via PLGA Nanoparticles Promotes Vascular Growth," American Journal of Physiology-Heart and Circulatory Physiology, Vol. 298, No. 6, 2010, pp. H1959-H1965. doi:10.1152/ajpheart.00199.2009

[117] C. R. Ozawa, A. Banfi, N. L. Glazer, G. Thurston, M. L. Springer, P. E. Kraft, D. M. McDonald and H. M. Blau, "Microenvironmental VEGF Concentration, Not Total Dose, Determines a Threshold between Normal and Aberrant Angiogenesis," The Journal of Clinical Investigation, Vol. 113, No. 4, 2004, pp. 516-527.

[118] E. A. Silva and D. J. Mooney, "Spatiotemporal Control of Vascular Endothelial Growth Factor Delivery from Injectable Hydrogels Enhances Angiogenesis," Journal of Thrombosis and Haemostasis, Vol. 5, No. 3, 2007, pp. 590-598. doi:10.1111/j.1538-7836.2007.02386.x

[119] E. A. Silva and D. J. Mooney, "Effects of VEGF Temporal and Spatial Presentation on Angiogenesis," Biomaterials, Vol. 31, No. 6, 2010, pp. 1235-1241. doi:10.1016/j.biomaterials.2009.10.052

[120] K. Bozaoglu, J. E. Curran, C. J. Stocker, M. S. Zaibi, D. Segal, N. Konstantopoulos, S. Morrison, M. Carless, T. D. Dyer, S. A. Cole, H. H. Goring, E. K. Moses, K. Walder, M. A. Cawthorne, J. Blangero and J.B. Jowett, "Chemerin, a Novel Adipokine in the Regulation of Angiogenesis," The Journal of Clinical Endocrinology \& Metabolism, Vol. 95, No. 5, 2010, pp. 2476-2485. doi: $10.1210 /$ jc. $2010-0042$

[121] O. Kunduzova, N. Alet, N. Delesque-Touchard, L. Millet, I. Castan-Laurell, C. Muller, C. Dray, P. Schaeffer, J. P. Herault, P. Savi, F. Bono and P. Valet, “Apelin/APJ Signaling System: A Potential Link between Adipose Tissue and Endothelial Angiogenic Processes," The FASEB Journal, Vol. 22, No. 12, 2008, pp. 4146-4153. doi:10.1096/fj.07-104018

[122] S. Uriel, E. M. Brey, and H. P. Greisler, "Sustained Low Levels of Fibroblast Growth Factor-1 Promote Persistent Microvascular Network Formation," The American Journal of Surgery, Vol. 192, No. 5, 2006, pp. 604-609. doi:10.1016/j.amjsurg.2006.08.012

[123] R. A. Marklein and J. A. Burdick, "Controlling Stem Cell Fate with Material Design," Advanced Materials, Vol. 22, No. 2, 2010, pp. 175-189. doi:10.1002/adma.200901055

[124] C. Theoret, "Tissue Engineering in Wound Repair: The Three 'R's-Repair, Replace, Regenerate," Veterinary Surgery, Vol. 38, No. 8, 2009, pp. 905-913. doi:10.1111/j.1532-950X.2009.00585.X

[125] L. Tian and S. C. George, "Biomaterials to Prevascularize Engineered Tissues," Journal of Cardiovascular Translational Research, Vol. 4, No. 5, 2011, pp. 685-698. doi:10.1007/s12265-011-9301-3

[126] K. Hemmrich, D. von Heimburg, R. Rendchen, C. Di Bartolo, E. Milella and N. Pallua, "Implantation of Preadipocyte-Loaded Hyaluronic Acid-Based Scaffolds into Nude 
Mice to Evaluate Potential for Soft Tissue Engineering," Biomaterials, Vol. 26, No. 34, 2005, pp. 7025-7037. doi:10.1016/j.biomaterials.2005.04.065

[127] T. A. Ahmed, E. V. Dare and M. Hincke, "Fibrin: A Versatile Scaffold for Tissue Engineering Applications," Tissue Engineering Part B: Reviews, Vol. 14, No. 2, 2008, pp. 199-215. doi:10.1089/ten.teb.2007.0435

[128] D. von Heimburg, S. Zachariah, I. Heschel, H. Kuhling, H. Schoof, B. Hafemann and N. Pallua, "Human Preadipocytes Seeded on Freeze-Dried Collagen Scaffolds Investigated in vitro and in vivo," Biomaterials, Vol. 22, No. 5, 2001, pp. 429-38. doi:10.1016/S0142-9612(00)00186-1

[129] A. M. Altman, Y. S. Yan, N. Matthias, X. W. Bai, C. Rios, A. B. Mathur, Y.-H. Song and E. U. Alt, "IFATS Collection: Human Adipose-Derived Stem Cells Seeded on a Silk Fibroin-Chitosan Scaffold Enhance Wound Repair in a Murine Soft Tissue Injury Model," Stem Cells, Vol. 27, No. 1, 2009, pp. 250-258.

doi:10.1634/stemcells.2008-0178

[130] A. Loebsack, K. Greene, S. Wyatt, C. Culberson, C. Austin, R. Beiler, W. Roland, P. Eiselt, J. Rowley, K. Burg, D. Mooney, W. Holder and C. Halberstadt, "In vivo Characterization of a Porous Hydrogel Material for Use as a Tissue Bulking Agent," Journal of Biomedical Materials Research, Vol. 57, No. 4, 2001, pp. 575-581. doi:10.1002/1097-4636(20011215)57:4<575::AID-JBM1 $\underline{204>3.0 . C O ; 2-9}$

[131] L. Flynn, J. L. Semple and K. A. Woodhouse, "Decellularized Placental Matrices for Adipose Tissue Engineering," Journal of Biomedical Materials Research Part A, Vol. 79A, No. 2, 2006, pp. 359-369. doi:10.1002/jbm.a.30762

[132] B. N. Brown, J. M. Freund, L. Han, J. P. Rubin, J. E. Reing, E. M. Jeffries, M. T. Wolf, S. Tottey, C. A. Barnes, B. D. Ratner and S. F. Badylak, "Comparison of Three Methods for the Derivation of a Biologic Scaffold Composed of Adipose Tissue Extracellular Matrix," Tissue Engineering Part C: Methods, Vol. 17, No. 4, 2011, pp. 411-421. doi:10.1089/ten.tec.2010.0342

[133] J. S. Choi, B. S. Kim, J. Y. Kim, J. D. Kim, Y. C. Choi, H.-J. Yang, K. Park, H. Y. Lee and Y. W. Cho, "Decellularized Extracellular Matrix Derived from Human Adipose Tissue as a Potential Scaffold for Allograft Tissue Engineering," Journal of Biomedical Materials Research Part A, Vol. 97A, No. 3, 2011, pp. 292-299. doi:10.1002/jbm.a.33056

[134] L. E. Flynn, "The Use of Decellularized Adipose Tissue to Provide an Inductive Microenvironment for the Adipogenic Differentiation of Human Adipose-Derived Stem Cells," Biomaterials, Vol. 31, No. 17, 2010, pp. 47154724. doi:10.1016/j.biomaterials.2010.02.046

[135] B. S. Kim, J. S. Choi, J. D. Kim, Y. C. Choi and Y. W. Cho, "Recellularization of Decellularized Human Adipose-Tissue-Derived Extracellular Matrix Sheets with Other Human Cell Types," Cell Tissue Research, 2012.

[136] H. Orbay, Y. Takami, H. Hyakusoku and H. Mizuno, "Acellular Dermal Matrix Seeded with Adipose-Derived Stem Cells as a Subcutaneous Implant," Aesthetic Plastic Surgery, Vol. 35, No. 5, 2011, pp. 756-763. doi:10.1007/s00266-011-9683-2
[137] N. Davidenko, J. J. Campbell, E. S. Thian, C. J. Watson, and R.E. Cameron, "Collagen-Hyaluronic Acid Scaffolds for Adipose Tissue Engineering," Acta Biomaterialia, Vol. 6, No. 10, 2010, pp. 3957-3968. doi:10.1016/j.actbio.2010.05.005

[138] S. Huang and X. Fu, "Naturally Derived Materials-Based Cell and Drug Delivery Systems in Skin Regeneration," Journal of Controlled Release, Vol. 142, No. 2, 2010, pp. 149-159. doi:10.1016/j.jconrel.2009.10.018

[139] L. Girandon, N. Kregar-Velikonja, K. Bozikov and A. Barlic, "In vitro Models for Adipose Tissue Engineering with Adipose-Derived Stem Cells Using Different Scaffolds of Natural Origin," Folia Biologica (Praha), Vol. 57, No. 2, 2011, pp. 47-56.

[140] F. P. Brandl, A. K. Seitz, J. K. Tessmar, T. Blunk and A. M. Gopferich, "Enzymatically Degradable Poly (Ethylene Glycol) Based Hydrogels for Adipose Tissue Engineering," Biomaterials, Vol. 31, No. 14, 2010, pp. 3957-3966. doi:10.1016/j.biomaterials.2010.01.128

[141] A. Alhadlaq, M. Tang and J. J. Mao, "Engineered Adipose Tissue from Human Mesenchymal Stem Cells Maintains Predefined Shape and Dimension: Implications in Soft Tissue Augmentation and Reconstruction," Tissue Engineering, Vol. 11, No. 3-4, 2005, pp. 556-566. doi:10.1089/ten.2005.11.556

[142] J.G. Kral and D. L. Crandall, "Development of a Human Adipocyte Synthetic Polymer Scaffold," Plastic and Reconstructive Surgery, Vol. 104, No. 6, 1999, pp. 17321738. doi:10.1097/00006534-199911000-00018

[143] X. Kang, Y. Xie, and D.A. Kniss, “Adipose Tissue Model Using Three-Dimensional Cultivation of Preadipocytes Seeded onto Fibrous Polymer Scaffolds," Tissue Engineering, Vol. 11, No. 3-4, 2005, pp. 458-468. doi:10.1089/ten.2005.11.458

[144] C. Fischbach, T. Spruss, B. Weiser, M. Neubauer, C. Becker, M. Hacker, A. Gopferich and T. Blunk, "Generation of Mature Fat Pads in vitro and in vivo Utilizing 3D Long-Term Culture of 3T3-L1 Preadipocytes," Experimental Cell Research, Vol. 300, No. 1, 2004, pp. 54-64. doi:10.1016/j.yexcr.2004.05.036

[145] H. S. Yang, J. Shin, S. H. Bhang, J.-Y. Shin, J. Park, G.-I. Im, C.-S. Kim and B.-S. Kim, "Enhanced Skin Wound Healing by a Sustained Release of Growth Factors Contained in Platelet-Rich Plasma," Experimental and Molecular Medicine, Vol. 43, No. 11, 2011, pp. 622-629. doi:10.3858/emm.2011.43.11.070

[146] G. Tae, M. Scatena, P. S. Stayton and A. S. Hoffman, "PEG-cross-Linked Heparin Is an Affinity Hydrogel for Sustained Release of Vascular Endothelial Growth Factor," Journal of Biomaterials Science, Polymer Edition, Vol. 17, No. 1-2, 2006, pp. 187-197. doi: $10.1163 / 156856206774879090$

[147] L. W. Chow, R. Bitton, M. J. Webber, D. Carvajal, K. R. Shull, A. K. Sharma and S. I. Stupp, "A Bioactive SelfAssembled Membrane to Promote Angiogenesis," Biomaterials, Vol. 32, No. 6, 2011, pp. 1574-1582. doi:10.1016/j.biomaterials.2010.10.048

[148] M. J. Webber, J. Tongers, C. J. Newcomb, K. T. Marquardt, J. Bauersachs, D. W. Losordo and S. I. Stupp, "Su- 
pramolecular Nanostructures that Mimic VEGF as a Strategy for Ischemic Tissue Repair," Proceedings of the National Academy of Sciences of the United States of America, Vol. 108, No. 33, 2011, pp. 13438-13443. doi: $10.1073 /$ pnas. 1016546108

[149] H. Cui, M. J. Webber and S. I. Stupp, "Self-Assembly of Peptide Amphiphiles: From Molecules to Nanostructures to Biomaterials," Peptide Science, Vol. 94, No. 1, 2010, pp. 1-18. doi:10.1002/bip. 21328

[150] R. L. Dahlin, F. K. Kasper and A. G. Mikos, "Polymeric Nanofibers in Tissue Engineering," Tissue Engineering Part B: Reviews, Vol. 17, No. 5, 2011, pp. 349-364. doi:10.1089/ten.teb.2011.0238

[151] M. I. Santos, K. Tuzlakoglu, S. Fuchs, M. E. Gomes, K. Peters, R .E. Unger, E. Piskin, R. L. Reis and C. J. Kirkpatrick, "Endothelial Cell Colonization and Angiogenic Potential of Combined Nano- and Micro-Fibrous Scaffolds for Bone Tissue Engineering," Biomaterials, Vol. 29, No. 32, 2008, pp. 4306-4313. doi:10.1016/j.biomaterials.2008.07.033

[152] M. J. Webber, J. Tongers, M. A. Renault, J. G. Roncalli, D. W. Losordo and S. I. Stupp, "Development of Bioactive Peptide Amphiphiles for Therapeutic Cell Delivery," Acta Biomaterialia, Vol. 6, No. 1, 2010, pp. 3-11. doi:10.1016/j.actbio.2009.07.031

[153] X. Chen, A. S. Aledia, S. A. Popson, L. Him, C. C. Hughes and S. C. George, "Rapid Anastomosis of Endothelial Progenitor Cell-Derived Vessels with Host Vasculature Is Promoted by a High Density of Cotransplanted Fibroblasts," Tissue Engineering Part A, Vol. 16, No. 2, 2010, pp. 585-594. doi:10.1089/ten.tea.2009.0491

[154] C. Deng, P. Zhang, B. Vulesevic, D. Kuraitis, F. Li, A. F. Yang, M. Griffith, M. Ruel and E. J. Suuronen, "A Collagen-Chitosan Hydrogel for Endothelial Differentiation and Angiogenesis," Tissue Engineering Part A, Vol. 16, No. 10, 2010, pp. 3099-3109. doi:10.1089/ten.tea.2009.0504

[155] I. Montano, C. Schiestl, J. Schneider, L. Pontiggia, J. Luginbuhl, T. Biedermann, S. Bottcher-Haberzeth, E. Braziulis, M. Meuli and E. Reichmann, "Formation of Human Capillaries in Vitro: The Engineering of Prevascularized Matrices," Tissue Engineering Part A, Vol. 16, No. 1, 2010, pp. 269-282. doi:10.1089/ten.tea.2008.0550

[156] R. E. Unger, S. Ghanaati, C. Orth, A. Sartoris, M. Barbeck, S. Halstenberg, A. Motta, C. Migliaresi and C. J. Kirkpatrick, "The Rapid Anastomosis between Prevascularized Networks on Silk Fibroin Scaffolds Generated in vitro with Cocultures of Human Microvascular Endothelial and Osteoblast Cells and the Host Vasculature," Biomaterials, Vol. 31, No. 27, 2010, pp. 6959-6967. doi:10.1016/j.biomaterials.2010.05.057

[157] T. Kaully, K. Kaufman-Francis, A. Lesman and S. Levenberg, "Vascularization-The Conduit to Viable Engineered Tissues," Tissue Engineering Part B: Reviews, Vol. 15, No. 2, 2009, pp. 159-169. doi: $10.1089 /$ ten.teb.2008.0193

[158] A. Breen, T. O'Brien and A. Pandit, "Fibrin as a Delivery System for Therapeutic Drugs and Biomolecules," Tissue Engineering Part B: Reviews, Vol. 15, No. 2, 2009, pp. 201-214. doi:10.1089/ten.teb.2008.0527
[159] E. Kniazeva, S. Kachgal and A. J. Putnam, "Effects of Extracellular Matrix Density and Mesenchymal Stem Cells on Neovascularization in Vivo," Tissue Engineering Part A, Vol. 17, No. 7-8, 2011, pp. 905-914. doi:10.1089/ten.tea.2010.0275

[160] E. A. Phelps, N. Landazuri, P. M. Thule, W. R. Taylor and A. J. Garcia, "Bioartificial Matrices for Therapeutic Vascularization," Proceedings of the National Academy of Sciences of the United States of America, Vol. 107, No. 8, 2010, pp. 3323-3328. doi:10.1073/pnas.0905447107

[161] M. W. Laschke, M. Rücker, G. Jensen, C. Carvalho, R. Mulhaupt, N. C. Gellrich and M. D. Menger, "Incorporation of Growth Factor Containing Matrigel Promotes Vascularization of Porous PLGA Scaffolds," Journal of Biomedical Materials Research Part A, Vol. 85, No. 2, 2008, pp. 397-407. doi:10.1002/jbm.a.31503

[162] M. T. Conconi, F. Ghezzo, M. Dettin, L. Urbani, C. Grandi, D. Guidolin, B. Nico, C. Di Bello, D. Ribatti and P. P. Parnigotto, "Effects on in vitro and in vivo Angiogenesis Induced by Small Peptides Carrying Adhesion Sequences," Journal of Peptide Science, Vol. 16, No. 7, 2010, pp. 349-357.

[163] M. Biondi, F. Ungaro, F. Quaglia and P. A. Netti, "Controlled Drug Delivery in Tissue Engineering," Advanced Drug Delivery Reviews, Vol. 60, No. 2, 2008, pp. 229242. doi:10.1016/j.addr.2007.08.038

[164] J. K. Tessmar and A. M. Gopferich, "Matrices and Scaffolds for Protein Delivery in Tissue Engineering," $A d$ vanced Drug Delivery Reviews, Vol. 59, No. 4-5, 2007, pp. 274-291. doi:10.1016/j.addr.2007.03.020

[165] J. D. Kretlow, L. Klouda and A. G. Mikos, "Injectable Matrices and Scaffolds for Drug Delivery in Tissue Engineering," Advanced Drug Delivery Reviews, Vol. 59, No. 4-5, 2007, pp. 263-273. doi:10.1016/j.addr.2007.03.013

[166] L. Requena, C. Requena, L. Christensen, U. S. Zimmermann, H. Kutzner and L. Cerroni, "Adverse Reactions to Injectable Soft Tissue Fillers," Journal of the American Academy of Dermatology, Vol. 64, No. 1, 2011, pp. 1-34. doi:10.1016/i.jaad.2010.02.064

[167] G. Lemperle, V. Morhenn and U. Charrier, "Human Histology and Persistence of Various Injectable Filler Substances for Soft Tissue Augmentation," Aesthetic Plastic Surgery, Vol. 27, No. 5, 2003, pp. 354-66. doi:10.1007/s00266-003-3022-1

[168] L. Baumann, J. Kaufman and S. Saghari, "Collagen Fillers," Dermatologic Therapy, Vol. 19, No. 3, 2006, pp. 134-140. doi:10.1111/j.1529-8019.2006.00067.x

[169] W. S. Kim, D. J. Mooney, P. R. Arany, K. Lee, N. Huebsch and J. Kim, "Adipose Tissue Engineering Using Injectable, Oxidized Alginate Hydrogels," Tissue Engineering Part A, Vol. 18, No. 7-8, 2012, pp. 737-743. doi:10.1089/ten.tea.2011.0250

[170] S.-W. Cho, S.-S. Kim, J.-W. Rhie, H.-M. Cho, C.-Y. Choi and B.-S. Kim, "Engineering of Volume-Stable Adipose Tissues," Biomaterials, Vol. 26, No. 17, 2005, pp. 35773585. doi:10.1016/j.biomaterials.2004.09.013

[171] N. Torio-Padron, N. Baerlecken, A. Momeni, G. B. Stark and J. Borges, "Engineering of Adipose Tissue by Injec- 
tion of Human Preadipocytes in Fibrin," Aesthetic Plastic Surgery, Vol. 31, No. 3, 2007, pp. 285-293. doi:10.1007/s00266-006-0221-6

[172] O. Khanna, M. L. Moya, H. P. Greisler, E. C. Opara and E. M. Brey, "Multilayered Microcapsules for the Sustained-Release of Angiogenic Proteins from Encapsulated Cells," The American Journal of Surgery, Vol. 200, No. 5, 2010, pp. 655-658. doi:10.1016/j.amjsurg.2010.08.001

[173] J. S. Park, H. N. Yang, D. G. Woo, S. Y. Jeon and K. H. Park, "The Promotion of Chondrogenesis, Osteogenesis, and Adipogenesis of Human Mesenchymal Stem Cells by Multiple Growth Factors Incorporated into NanosphereCoated Microspheres," Biomaterials, Vol. 32, No. 1, 2011, pp. 28-38. doi:10.1016/j.biomaterials.2010.08.088

[174] S.-W. Kang, S.-W. Seo, C.-Y. Choi and B.-S. Kim, "Porous Poly (Lactic-Co-Glycolic Acid) Microsphere as Cell Culture Substrate and Cell Transplantation Vehicle for Adipose Tissue Engineering," Tissue Engineering Part C: Methods, Vol. 14, No. 1, 2008, pp. 25-34. doi:10.1089/tec.2007.0290

[175] Y.-S. Choi, S.-N. Park and H. Suh, “Adipose Tissue Engineering Using Mesenchymal Stem Cells Attached to Injectable PLGA Spheres," Biomaterials, Vol. 26, No. 29, 2005, pp. 5855-5863. doi:10.1016/j.biomaterials.2005.02.022

[176] K. G. Marra, A. J. Defail, J. A. Clavijo-Alvarez, S. F. Badylak, A. Taieb, B. Schipper, J. Bennett and J. P. Rubin, "FGF-2 Enhances Vascularization for Adipose Tissue Engineering," Plastic and Reconstructive Surgery, Vol. 121, No. 4, 2008, pp. 1153-1164. doi:10.1097/01.prs.0000305517.93747.72

[177] J. P. Rubin, J. M. Bennett, J. S. Doctor, B. M. Tebbets and K. G. Marra, "Collagenous Microbeads as a Scaffold for Tissue Engineering with Adipose-Derived Stem Cells," Plastic and Reconstructive Surgery, Vol. 120, No. 2, 2007, pp. 414-424. doi:10.1097/01.prs.0000267699.99369.a8

[178] S. Natesan, D. G. Baer, T. J. Walters, M. Babu and R. J. Christy, "Adipose-Derived Stem Cell Delivery into Collagen Gels Using Chitosan Microspheres," Tissue Engineering Part A, Vol. 16, No. 4, 2010, pp. 1369-1384. doi:10.1089/ten.tea.2009.0404

[179] M. L. Moya, M.-H. Cheng, J.-J. Huang, M. E. Francis-Sedlak, S.-W. Kao, E. C. Opara and E. M. Brey, "The Effect of FGF-1 Loaded Alginate Microbeads on Neovascularization and Adipogenesis in a Vascular Pedicle Model of Adipose Tissue Engineering," Biomaterials, Vol. 31, No. 10, 2010, pp. 2816-2826. doi:10.1016/j.biomaterials.2009.12.053

[180] D. A. Young, D. O. Ibrahim, D. Hu and K. L. Christman, "Injectable Hydrogel Scaffold from Decellularized Human Lipoaspirate," Acta Biomaterialia, Vol. 7, No. 3, 2011, pp. 1040-1049. doi:10.1016/j.actbio.2010.09.035

[181] K. D. Song, M. Qiao, T. Q. Liu, B. Jiang, H. M. Macedo, X. H. Ma and Z. F. Cui, "Preparation, Fabrication and Biocompatibility of Novel Injectable Temperature-Sensitive Chitosan/Glycerophosphate/Collagen Hydrogels," Chemistry and Materials Science, Vol. 21, No. 10, 2010, pp. 2835-2842. doi:10.1007/s10856-010-4131-4

[182] J. S. Choi, H. J. Yang, B. S. Kim, J. D. Kim, J. Y. Kim, B.
Yoo, K. Park, H. Y. Lee and Y. W. Cho, "Human Extracellular Matrix (Ecm) Powders for Injectable Cell Delivery and Adipose Tissue Engineering," Journal of Controlled Release, Vol. 139, No. 1, 2009, pp. 2-7. doi:10.1016/j.jconrel.2009.05.034

[183] A. E. Turner and L. E. Flynn, "Design and Characterization of Tissue-Specific Extracellular Matrix-Derived Microcarriers," Tissue Engineering Part C: Methods, Vol. 18, No. 3, 2012, pp. 186-197.

doi: $10.1089 /$ ten.tec. 2011.0246

[184] A. T. Hillel, S. Unterman, Z. Nahas, B. Reid, J. M. Coburn, J. Axelman, J. J. Chae, Q. Guo, R. Trow, A. Thomas, Z. Hou, S. Lichtsteiner, D. Sutton, C. Matheson, P. Walker, N. David, S. Mori, J. M. Taube and J. H. Elisseeff, "Photoactivated Composite Biomaterial for Soft Tissue Restoration in Rodents and in Humans," Science Translational Medicine, Vol. 3, No. 93, 2011, p. 93ra67. doi:10.1126/scitranslmed.3002331

[185] E. M. Horwitz and W. R. Prather, "Cytokines as the Major Mechanism of Mesenchymal Stem Cell Clinical Activity: Expanding the Spectrum of Cell Therapy," Israel Medical Association Journal, Vol. 11, No. 4, 2009, pp. 209-211.

[186] A. T. Hillel, S. Varghese, J. Petsche, M. J. Shamblott and J. H. Elisseeff, "Embryonic Germ Cells Are Capable of Adipogenic Differentiation in Vitro and in Vivo," Tissue Engineering Part A, Vol. 15, No. 3, 2009, pp. 479-486. doi:10.1089/ten.tea.2007.0352

[187] C. Dani, "Embryonic Stem Cell-Derived Adipogenesis," Cells Tissues Organs, Vol. 165, No. 3-4, 1999, pp. 173180. doi:10.1159/000016697

[188] D. Nichol and H. Stuhlmann, "EGFL7: A Unique Angiogenic Signaling Factor in Vascular Development and Disease," Blood, Vol. 119, No. 6, 2012, pp. 1345-1352. doi:10.1182/blood-2011-10-322446

[189] S. Y. Liu, H. M. Zhang, X. J. Zhang, W. Lu, X. H. Huang, H. Xie, J. Zhou, W. H. Wang, Y. J. Zhang, Y. Liu, Z. H. Deng and Y. Jin, "Synergistic Angiogenesis Promoting Effects of Extracellular Matrix Scaffolds and AdiposeDerived Stem Cells During Wound Repair," Tissue Engineering Part A, Vol. 17, No. 5-6, 2011, pp. 725-739. doi:10.1089/ten.tea.2010.0331

[190] S. P. Zhong, Y. Z. Zhang and C. T. Lim, "Tissue Scaffolds for Skin Wound Healing and Dermal Reconstruction," Wiley Interdisciplinary Reviews: Nanomedicine and Nanobiotechnology, Vol. 2, No. 5, 2010, pp. 510-525. doi:10.1002/wnan. 100

[191] M. C. Zingaretti, F. Crosta, A. Vitali, M. Guerrieri, A. Frontini, B. Cannon, J. Nedergaard and S. Cinti, "The Presence of UCP1 Demonstrates That Metabolically Active Adipose Tissue in the Neck of Adult Humans Truly Represents Brown Adipose Tissue," The FASEB Journal, Vol. 23, No. 9, 2009, pp. 3113-3120. doi:10.1096/fj.09-133546

[192] A. Asano, M. Morimatsu, H. Nikami, T. Yoshida and M. Saito, "Adrenergic Activation of Vascular Endothelial Growth Factor mRNA Expression in Rat Brown Adipose Tissue: Implication in Cold-Induced Angiogenesis," Biochemical Journal, Vol. 328, 1997, pp. 179-183. 
[193] A. Asano, K. Kimura and M. Saito, "Cold-Induced mRNA Expression of Angiogenic Factors in Rat Brown Adipose Tissue," Journal of Veterinary Medical Science, Vol. 61, No. 4, 1999, pp. 403-409. doi:10.1292/jvms.61.403

[194] E. A. Neofytou, E. Chang, B. Patlola, L. M. Joubert, J. Rajadas, S. S. Gambhir, Z. Cheng, R. C. Robbins and R. E. Beygui, "Adipose Tissue-Derived Stem Cells Display a
Proangiogenic Phenotype on 3D Scaffolds," Journal of Biomedical Materials Research Part A, Vol. 98, No. 3, 2011, pp. 383-393. doi:10.1002/jbm.a.33113

[195] N. Cuende and A. Izeta, "Clinical Translation of Stem Cell Therapies: A Bridgeable Gap," Cell Stem Cell, Vol. 6, No. 6, 2010, pp. 508-512. doi:10.1016/j.stem.2010.05.005 